\title{
Suspended particles in the Canada Basin from optical and bottle data, 2003-2008
}

\author{
J. M. Jackson ${ }^{1}$, S. E. Allen ${ }^{1}$, E. C. Carmack ${ }^{2}$, and F. A. McLaughlin ${ }^{2}$ \\ ${ }^{1}$ Department of Earth and Ocean Sciences, University of British Columbia, 6339 Stores Rd, Vancouver, BC V6T 1Z4, Canada \\ ${ }^{2}$ Fisheries and Oceans Canada, Institute of Ocean Sciences, P. O. Box 6000, Sidney, British Columbia V8L 4B2, Canada
}

Received: 5 May 2010 - Published in Ocean Sci. Discuss.: 26 May 2010

Revised: 7 September 2010 - Accepted: 8 September 2010 - Published: 22 September 2010

\begin{abstract}
It is expected that coastal erosion, upwelling, and increased river runoff from Arctic warming will increase the concentration of suspended particles in the Arctic Ocean. Here we analyze in situ transmissometer and fluorometer data from the summers of 2003 through 2008 and bottle-derived particulate organic carbon (POC) and total suspended solids (TSS) measurements sampled in the summers of 2006 and 2007 from the Canada Basin and surrounding shelves. We divided our study area into five regions to account for the significant spatial variability and found that the highest attenuation, POC and TSS values were observed along the Beaufort shelf and the lowest values were located along the eastern shelf of the Canada Basin. We then explored the correlation of POC and TSS with beam attenuation coefficients to assess the viability of estimating POC concentrations from archived transmissometer data. POC (but not TSS) and attenuation were well-correlated over the Northwind Ridge, in the Canada Basin interior, and along the eastern shelf of the Canada Basin. Neither TSS nor POC were well-correlated with attenuation along the entire Beaufort shelf. An interannual comparison of the attenuation and fluorescence data was done. We found no evidence of increasing attenuation from the summers of 2003 through 2008 and, although not statistically significant, it even appeared that attenuation decreased over time in the upper $25 \mathrm{~m}$ of the Northwind Ridge and in the 25-100 m layer (that includes the chlorophyll maximum) of the eastern Beaufort shelf and within the Canada Basin. In the Canada Basin interior, the subsurface chlorophyll maximum deepened at a rate of $3.2 \mathrm{~m}$ per year from an average of $45 \mathrm{~m}$ in 2003 to $61 \mathrm{~m}$ in 2008, an example of how changes to the Arctic climate are impacting its ecology.
\end{abstract}

Correspondence to: J. M. Jackson (jjackson@eos.ubc.ca)

\section{Introduction}

Climate change is predicted to increase upwelling, coastal erosion and river runoff and these effects will likely increase suspended particle concentrations in the Arctic Ocean and its surrounding shelves (Carmack et al., 2006). Particles supplied by these processes in the western Arctic Ocean (see map in Fig. 1) are primarily inorganic (Macdonald et al., 1998; O'Brien et al., 2006). Suspended particles influence the near-surface optical environment by scattering and absorbing sunlight, which may affect rates of primary productivity.

Historical measurements of total suspended solids (TSS i.e. both inorganic and organic particles) and particulate organic carbon (POC) in the western Arctic Ocean are limited. The first reported TSS and POC data from the Canada Basin, collected in the spring of 1968 and 1969 at Ice Station T3 , were $9-56 \mu \mathrm{g} \mathrm{kg}^{-1}$ and $2-14 \mu \mathrm{gC} \mathrm{kg}-1$, respectively, with the highest values of both observed at $50 \mathrm{~m}$ (Kinney et al., 1971). Similar values for POC were found in April 1983 along the Alpha Ridge during the CESAR program (Gordon and Cranford, 1985). The above concentrations were among the lowest ever observed for an open ocean system, and thus the Canada Basin was described as a biological desert (Kinney et al., 1971; Gordon and Cranford, 1985). In 1994, POC samples were collected in summer during the joint CanadaUS expedition from the Chukchi Sea to the North Pole and values in the upper $100 \mathrm{~m}$ were about five times greater than previous estimates, suggesting that the Canada Basin is seasonally productive (Wheeler et al., 1997) and actively cycles carbon (Wheeler et al., 1996).

Several studies have examined the transport of particles from Arctic shelves to the Canada Basin. During ice-island T3 from 1965-69, several nepheloid layers were identified along the Northwind Ridge that likely transported particles into the deep Canada Basin (Hunkins et al., 1969). At the

Published by Copernicus Publications on behalf of the European Geosciences Union. 


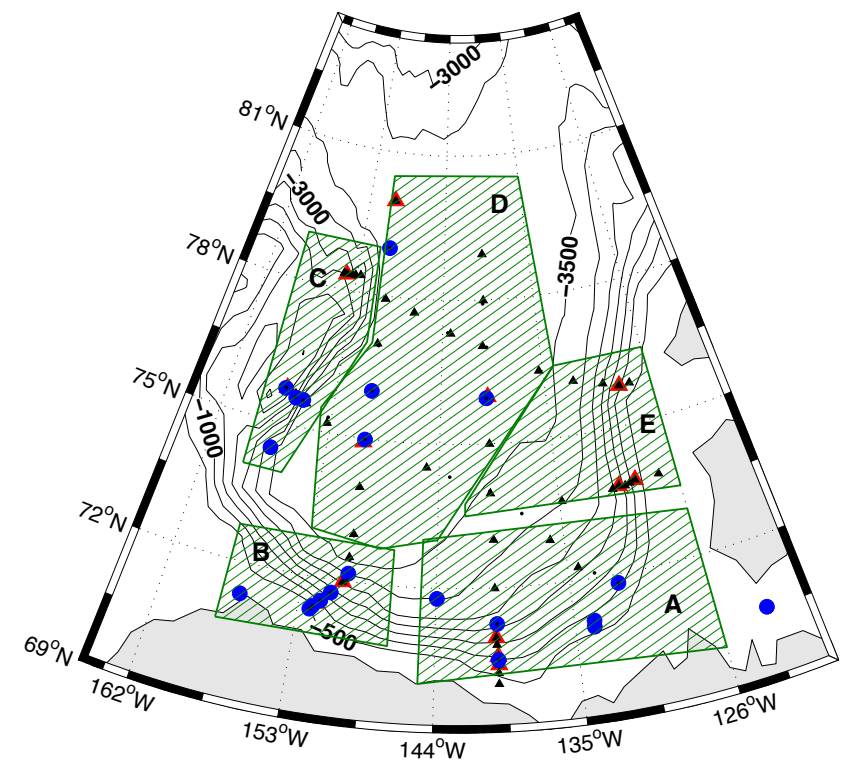

Fig. 1. Bathymetric map of the stations where POC and TSS were sampled in 2006 (blue circles) and 2007 (red triangles). Contoured depths are labeled in meters at $500 \mathrm{~m}$ intervals. Small black circles (2006) and triangles (2007) represent stations where the CTD and sensors were deployed but no POC or TSS were sampled. This study area was separated into 5 regions over which the POC and TSS was averaged at each sampling level. These are (A) the eastern Beaufort shelf that includes the Mackenzie Trough, (B) the western Beaufort shelf that includes the Barrow Canyon, (C) the eastern Northwind Ridge slope, (D) the interior of the Canada Basin, and E) the eastern Canada Basin shelf between Banks Island and Prince Patrick Island.

surface, it has been found that particles in modified Mackenzie River runoff (O'Brien et al., 2006; Lalande et al., 2009) and in Lena River runoff (Burenkov, 1993; Lalande et al., 2009) can end up in the Canada Basin (Yamamoto-Kawai et al., 2009; Guay et al., 2009). Dirty sea ice can also release particles in situ if it melts (Darby, 2003). During the 2002 Western Arctic Shelf-Basin Interactions (SBI) summer cruise, several plumes of particles at various depths below $50 \mathrm{~m}$ were identified that likely transported matter from the Chukchi and western Beaufort shelf into the Canada Basin (Ashjian et al., 2005; Bates et al., 2005; Codispoti et al., 2005). Mechanisms to transport this material include advection through Barrow Canyon (Ashjian et al., 2005) and advection of eddies that are formed within the particle-rich along-shelf boundary current (Pickart, 2004; Ashjian et al., 2005; Mathis et al., 2007).

Particle concentrations can also be approximated from transmissometer (measures light attenuation) and fluorometer (approximates chlorophyll $a$ ) data, both of which have been measured more extensively in the Canada Basin and surrounding shelves than POC and TSS. It has been found that POC and TSS are well correlated with attenuation in
Puget Sound (Baker and Lavelle, 1984), along the continental rise of the northwest Atlantic (Gardner et al., 1985), in the Gulf Stream (Bishop, 1986), in the Laptev Sea near the Lena River delta (Burenkov, 1993), in the equatorial Pacific (Bishop, 1999) and in the subarctic Pacific (Bishop et al., 1999). However, these relationships have not been tested in the Canada Basin.

During the summers of 2003 through 2008, CTD, transmissometer and fluorometer data were collected at stations in the Canada Basin and its surrounding shelves. In addition, POC and TSS samples were taken during the 2006 and 2007 cruises (Fig. 1). Here, we examine these data to (i) identify regions of high attenuation, fluorescence, POC and TSS (Sect. 3), to (ii) examine the interannual variability of these data (Sect. 4), and to (iii) determine the correlation between TSS and attenuation and POC and attenuation (Sect. 5).

\section{Data and methods}

\subsection{CTD, transmissometer and fluorescence data}

For this study, researchers from Fisheries and Oceans Canada in collaboration with researchers from the Japan Agency for Marine-Earth Science and Technology and Woods Hole Oceanographic Institution collected temperature, salinity, fluorescence and transmissometer data from 2003 to 2008 (details in McLaughlin et al., 2008). The $2410 \mathrm{~L}$ Niskin bottles and the sensors were deployed on the same rosette. During all years, a SeaBird SBE-911 Plus CTD, a Wetlabs Cstar transmissometer, and a Seapoint fluorometer were used. The cruise dates were: 13 August-3 September, 2003; 530 August, 2004; 3-31 August, 2005; 7 August-12 September, 2006; 27 July-28 August, 2007; and 23 July-20 August, 2008. Transmissometer data were collected at $662 \mathrm{~nm}$. The Seapoint fluorometer measured chlorophyll $a$ and its excitation and emission wavelengths were $470 \mathrm{~nm}$ and $685 \mathrm{~nm}$, respectively.

An initial assessment of the transmissometer data revealed significant drift (up to $2 \%$ ) between years and even during the same cruise, likely due to variable frequency of cleaning the optical window. In order to compare all transmissometer data, we calibrated all profiles to station CB11, sampled on 1 September, 2006 at $79^{\circ} \mathrm{N}, 150^{\circ} \mathrm{W}$ with a freshly calibrated Wetlabs C-star transmissometer. To perform the calibration, we assumed that the water at $2000 \mathrm{~m}$ at all stations in the Canada Basin (i.e. with a bottom depth greater than $3500 \mathrm{~m}$ ) was clear. A depth of $2000 \mathrm{~m}$ was chosen because it was found to be the clearest water in the Arctic Ocean when the bottom depth was greater than $3000 \mathrm{~m}$ (Hunkins et al., 1969). At each basin station, we subtracted $90.7 \%$ (the transmissometer value at $\mathrm{CB} 11$ at $2000 \mathrm{~m}$ in 2006) from the transmissometer value at $2000 \mathrm{~m}$ at that station and then added this difference to each data point to calibrate the remaining transmissometer profile. For shallower stations, we averaged 
the calibration from the nearest basin stations. A similar calibration was done for fluorescence data. Here, the data were calibrated to the fluorometer value observed at $2000 \mathrm{~m}$ at CB11 in $2006\left(0.0347 \mu \mathrm{gL}^{-1}\right)$ and the basin profiles were calibrated based on the difference between the value at CB11 and the value at each station at $2000 \mathrm{~m}$.

It has been shown that transmissometer output are affected by differences between the internal temperature of the transmissometer and the temperature of the seawater, especially in cold, clear water (Bishop, 1986). In particular, Bishop (1986) found that a temperature difference of about $11^{\circ} \mathrm{C}$ amounts to $9-12 \mu \mathrm{g} \mathrm{kg}^{-1}$ of total suspended solids in open oceans. Our Wetlabs C-star transmissometer, subjected to temperature stability tests, had a maximum transmissometer error of $0.02 \%$ per degree Celsius difference, which is less than half of the $0.05 \%$ transmission error per degree Celsius found by Bishop (1986). To further minimize these effects, the transmissometer was soaked at $5 \mathrm{~m}$ for $3 \mathrm{~min}$ before each cast.

To determine the amount of light that is attenuated due to both scattering and absorption of particles, we calculated the beam attenuation coefficient $(C)$ as $C=-\ln (\operatorname{Tr}) / r$ where $\operatorname{Tr}$ was the observed transmissometer value and $r$, the path length of the transmissometer, was $0.25 \mathrm{~m}$ (Bishop, 1986).

\subsection{POC and TSS data}

In 2006 and 2007, POC samples were taken at $5 \mathrm{~m}$ and $20 \mathrm{~m}$, at the fluorometer maximum, at salinities 32.3, 32.6, 32.9, $33.1,34.4$, at the bottom and at any interesting transmissometer features. Nineteen stations were sampled in 2006 and 12 in 2007 . Water was subsampled directly from $10 \mathrm{~L}$ Niskin bottles into two pre-calibrated, acid cleaned $2 \mathrm{~L}$ Nalgene bottles. The spigot was a few centimetres above the bottom of the Niskin bottles so, as found by Gardner (1977), it is possible that some of the particles could have settled to the bottom of the Niskin bottles before they were sampled. Onboard ship, the $4 \mathrm{~L}$ samples were filtered onto $47 \mathrm{~mm}$ Advantec GF75 filters in 2006 and 25 mm Advantec GF75 filters in 2007 that had been pre-combusted at $500{ }^{\circ} \mathrm{C}$ for $4 \mathrm{~h}$. A vacuum pump whose pressure did not exceed $7 \mathrm{psi}\left(4.82 \mathrm{Ncm}^{-2}\right)$ was used during filtration. The filtration castles were rinsed down with double-filtered MilliQ water just before the filtration was complete. The filters were then placed in a labeled $50 \mathrm{~mm}$ glass Petri dish and frozen at $-20^{\circ} \mathrm{C}$. The filtration time and the volume of water filtered were recorded and filtration was performed within $4 \mathrm{~h}$ of sampling.

Once on shore, the filters were dried for $24 \mathrm{~h}$ at $50^{\circ} \mathrm{C}, \mathrm{HCl}$ fumed for $48 \mathrm{~h}$, then dried again at $50^{\circ} \mathrm{C}$ for $24 \mathrm{~h}$, wrapped in aluminum foil and pressed into pellets. The pellets were analyzed using a Carlo Erba $\mathrm{CN}$ analyzer, located in the Department of Earth and Ocean Sciences at UBC, to determine POC. Sulfanilamide and blank cups were used as standards. Duplicates were taken at least once per cast in 2007 and the average standard deviation of the 10 duplicates was $6.3 \mu \mathrm{gC} \mathrm{kg}^{-1}$, which was $29 \%$ of the average 2007 POC value of $21.4 \mu \mathrm{gC} \mathrm{kg}^{-1}$. It should be noted that 9 POC samples were destroyed during analysis in 2007, including $3 \mathrm{du}-$ plicates.

TSS samples were taken at $5 \mathrm{~m}, 20 \mathrm{~m}$, at the fluorometer maximum and at any interesting transmissometer feature in 2006. In 2007, samples were taken at the same depths as the POC samples. In 2006, 16 stations were sampled and in 2007, 12 stations were sampled. Water was subsampled directly from $10 \mathrm{~L}$ Niskin bottles into two or three precalibrated acid cleaned $2 \mathrm{~L}$ Nalgene bottles. Onboard ship, 4-6 L were filtered onto $47 \mathrm{~mm}$ Poretics $0.4 \mu \mathrm{m}$ polycarbonate nucleopore filters that had been acid cleaned, rinsed with double-filtered MilliQ water, dried at $50^{\circ} \mathrm{C}$ and pre-weighed to $0.001 \mathrm{mg}$. A vacuum pump that did not exceed $7 \mathrm{psi}$ $\left(4.82 \mathrm{Ncm}^{-2}\right)$ was used during filtration. The filtration castles were rinsed down with double-filtered MilliQ water just before the filtration was complete. The filters were rinsed with 3\% ammonium carbonate solution after filtration was complete, placed in a labeled $50 \mathrm{~mm}$ plastic Petri dish, and frozen at $-20^{\circ} \mathrm{C}$. The time of filtration and the volume of water filtered were recorded and filtration was performed within $4 \mathrm{~h}$ of sampling.

Once on shore, the TSS samples were dried at $50^{\circ} \mathrm{C}$ for $24 \mathrm{~h}$ and then weighed. The TSS concentration was equal to the final weight minus the initial weight divided by the volume of water filtered. In 2006, the Satorius LE225D scale used to pre-weigh the filters was not available and a Mettler Toledo XP205 scale was used instead. By comparison of pre-weighed Petri dishes, it was found that the Petri dishes weighed on average (with standard deviation) 0.00057 $( \pm 0.00009) \mathrm{g}$ less on the new scale so $0.00057 \mathrm{~g}$ was added to the final weight of the filters. The Mettler Toledo XP205 scale was used in 2007. Duplicates were taken at least once per cast in 2007 and the average standard deviation of these 13 duplicates was $25.5 \mu \mathrm{g} \mathrm{kg}^{-1}$, which was $25 \%$ of the average 2007 TSS value of $103 \mu \mathrm{g} \mathrm{kg}^{-1}$.

\section{Results}

An initial evaluation of the sensor and bottle data showed substantial spatial variability, so we chose to divide the data into five different geographic regions of the Canada Basin for analysis (Fig. 1). These are (i) the eastern Beaufort shelf, a shelf-slope region in the southeastern Canada Basin with a bottom depth less than $3500 \mathrm{~m}$ that is influenced by outflow from the Mackenzie River; (ii) the western Beaufort shelf, a shelf-slope area with a bottom depth less than $3500 \mathrm{~m}$ that includes Barrow Canyon; (iii) the eastern Northwind Ridge slope, a feature with depths from about $950-3500 \mathrm{~m}$ between the Northwind Abyssal Plain and the Canada Basin, (iv) the Canada Basin interior, with a bottom depth greater than $3500 \mathrm{~m}$; and (v) the eastern Canada Basin shelf, a shelfslope area with a bottom depth less than $3500 \mathrm{~m}$ that lies 

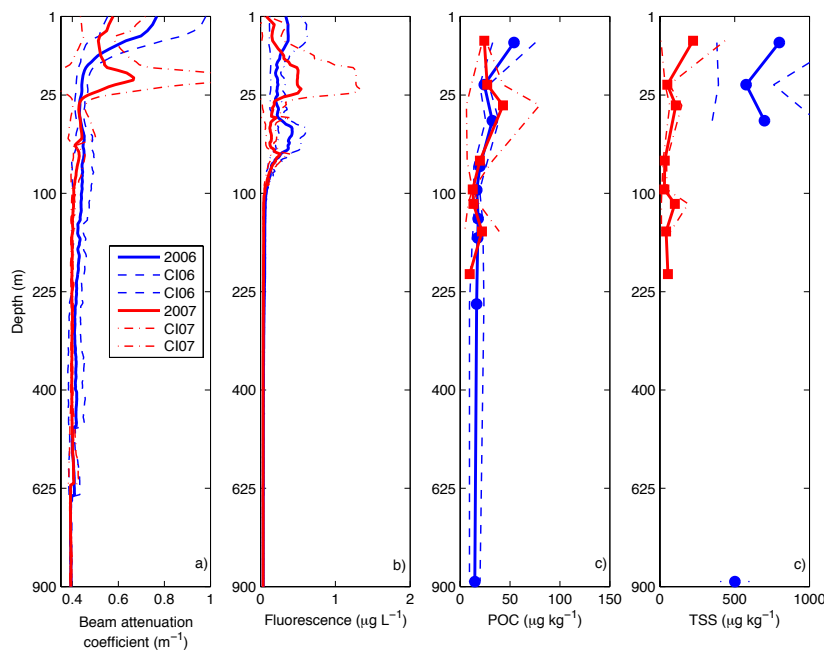

Fig. 2. Average profiles of (a) beam attenuation coefficient, (b) fluorescence, (c) POC, and (d) TSS in the eastern Beaufort shelf region for 2006 (blue lines) and 2007 (red lines). The vertical axis is nonlinear (square root) to emphasize the near-surface features. Only the upper $900 \mathrm{~m}$ are shown because there were no attenuation features or bottle samples below this depth. The red and blue dashed lines represent the 95\% confidence intervals for 2006 and 2007, respectively. For beam attenuation coefficient only, the $5 \mathrm{~m}$ centred running mean is plotted to smooth the data. The blue circles and red squares represent the average sampling depth for POC and TSS in 2006 and 2007, respectively.

between Banks and Prince Patrick Islands. Average profiles of beam attenuation, fluorescence, POC and TSS within each region were prepared for comparison (Figs. 2-6).

\subsection{The eastern Beaufort Shelf}

Overall, the highest TSS concentrations (maximum $1789 \mathrm{\mu g} \mathrm{kg}^{-1}$ in the surface water in 2006) were observed in the eastern Beaufort shelf. The average profiles of beam attenuation (Fig. 2) showed that the water was relatively clear below about $250 \mathrm{~m}$, with the most particle-rich water in the upper $25 \mathrm{~m}$. In this region, the highest attenuation, POC and TSS were seen above $10 \mathrm{~m}$ in 2006. In 2007, the surface water also had high attenuation but relatively low TSS and POC concentrations. It is likely that the source of particles in this area was the Mackenzie River. Based on oxygen isotopes and alkalinity, Yamamoto-Kawai et al. (2009) found about double the amount of Mackenzie water here in 2007 than 2006, which suggests that the quantity of Mackenzie water itself is not a good indicator of TSS or POC concentration. O'Brien et al. (2006) attribute much of the spatial and temporal variability of suspended particles here to both the strength of the Mackenzie plume during freshet and to variable wind transport, which may cause either the resuspension of particles during north-westerly winds
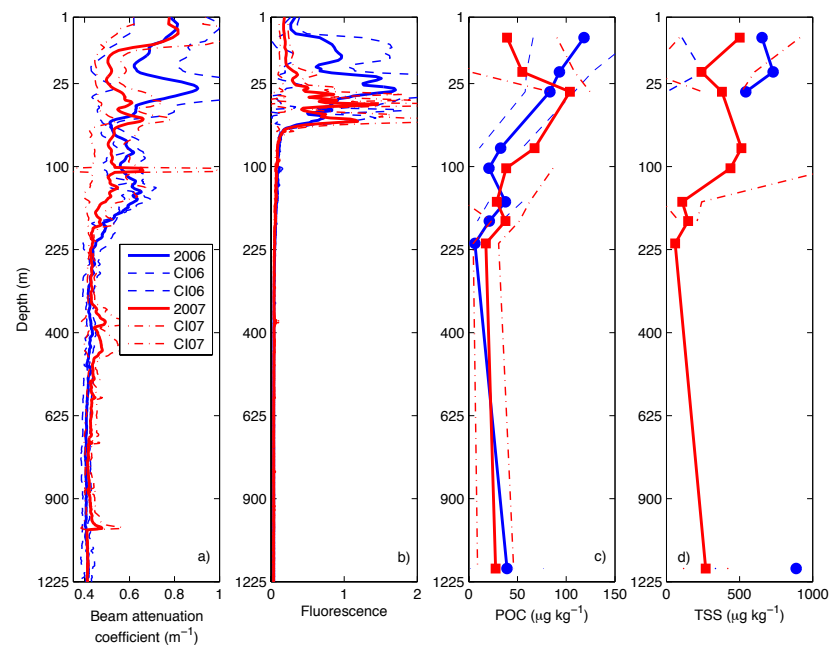

Fig. 3. As in Fig. 2 but for the western Beaufort shelf region. The upper $1600 \mathrm{~m}$ are shown to include all attenuation features and bottle samples.

or the erosion of coastlines during south-easterly winds. Proshutinsky et al. (2009) found that the winds were more upwelling favourable in 2007 so more coastal erosion would be expected that year. Thus, since neither the resuspension of particles nor coastal erosion were greater in 2006, it is likely that the higher surface particle concentrations observed were due to a higher Mackenzie River particle load. Below the surface, attenuation was low in 2006 although a fluorescence and POC signal at about $50 \mathrm{~m}$ indicate the ubiquitous deep chlorophyll maximum (Lee and Whitledge, 2005; Nishino et al., 2008; Martin et al., 2010). Both the near-surface and subsurface fluorescence maxima were deeper in 2007 than 2006. In general, the water column had higher attenuation and TSS concentrations in 2006 than 2007.

\subsection{The western Beaufort Shelf}

The western Beaufort shelf had the highest observed POC concentrations of the study area (Fig. 3), with a maximum value of $192 \mu \mathrm{gC} \mathrm{kg}^{-1}$ at $5 \mathrm{~m}$ over the shelf in 2006 . This is similar to surface water values sampled at the same location during the 2002 SBI project (Bates et al., 2005). In 2007, the surface water also had high attenuation, however, POC was low, which indicates that most of the particles were inorganic. Below the surface, the western Beaufort shelf also had the most variable attenuation profile of the regions sampled, with three main attenuation features above $1000 \mathrm{~m}$ in 2006 and five in 2007.

In 2006, the three features were (i) A high POC, high fluorescence signal at about $25 \mathrm{~m}$ that represents the chlorophyll maximum; (ii) High attenuation from about $75-100 \mathrm{~m}$ that had low POC; and (iii) A high POC layer from about 100$200 \mathrm{~m}$ that was observed in an eddy of cold Pacific winter 

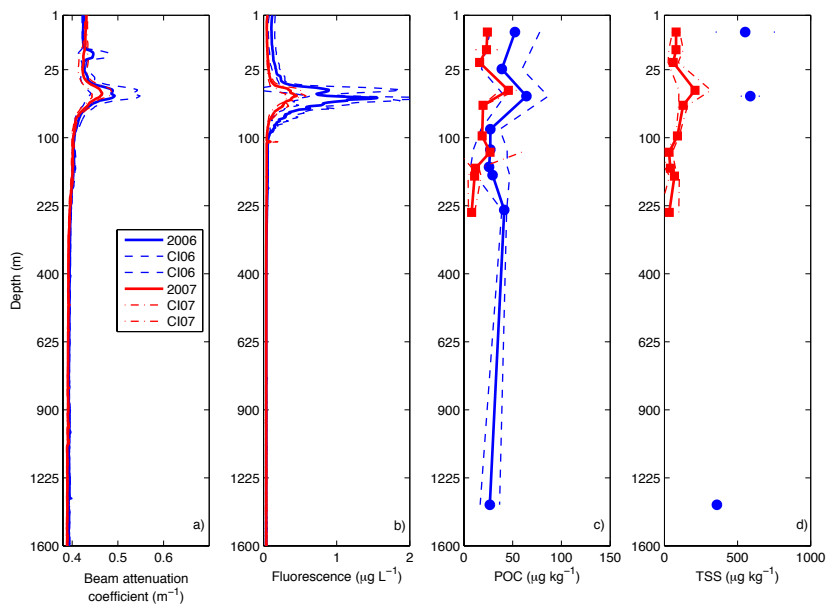

Fig. 4. As in Fig. 2 but for the eastern Northwind Ridge slope region. The upper $1600 \mathrm{~m}$ are shown to include all attenuation features and bottle samples. The value on the horizontal axis for beam attenuation coefficient is about half of the value in Figs. $2 \mathrm{a}$ and $3 \mathrm{a}$.

water (PWW, defined by a salinity of 33.1 as per Jones and Anderson, 1986). During the 2002 SBI project, Ashjian et al. (2005) found high concentrations of marine snow (up to about $20 \mu \mathrm{gC} \mathrm{kg}^{-1}$ ) within PWW at the same location. We found similar POC concentrations of up to $29 \mu \mathrm{gC} \mathrm{kg}-1$ within PWW. In 2007, the five subsurface attenuation features were (i) The high fluorescence, high POC chlorophyll maximum from $30-50 \mathrm{~m}$; (ii) Near $100 \mathrm{~m}$, there was nonfluorescent water with a very high TSS concentration of $806 \mu \mathrm{gg}^{-1}$. This feature was within Pacific Summer Water (salinity of 32.7) and, as described by Pickart (2004), the sloping isohalines (not shown) indicate the eastward flowing Beaufort shelfbreak jet. High concentrations can thus be explained by shear-induced re-suspension of particles caused by the current; (iii) A high POC (up to $46 \mu \mathrm{gC} \mathrm{kg}^{-1}$ ) and TSS (up to $180 \mu \mathrm{g} \mathrm{kg}^{-1}$ ) signal within PWW that was likely marine snow; (iv) An attenuation feature at about $400 \mathrm{~m}$ within Atlantic water (salinity of 34.83). This feature was most apparent in the shallow station (bottom depth of $500 \mathrm{~m}$ ), thus it could be from particle resuspension associated with a boundary current of Atlantic water; (v) An attenuation feature at about $1000 \mathrm{~m}$. This water had a salinity of 34.88 and the station had a bottom depth of $2000 \mathrm{~m}$.

\subsection{The eastern Northwind Ridge slope}

The attenuation features on the eastern Northwind Ridge slope were all above $100 \mathrm{~m}$ (Fig. 4). In 2006, a nonfluorescent, low-POC feature was observed at about $20 \mathrm{~m}$ that was not apparent in 2007. From the same 2006 cruise, Jackson et al. (2010) found a summer halocline at this depth and Yamamoto-Kawai et al. (2009) observed a relatively high fraction of sea ice melt at the surface. Thus we suggest that

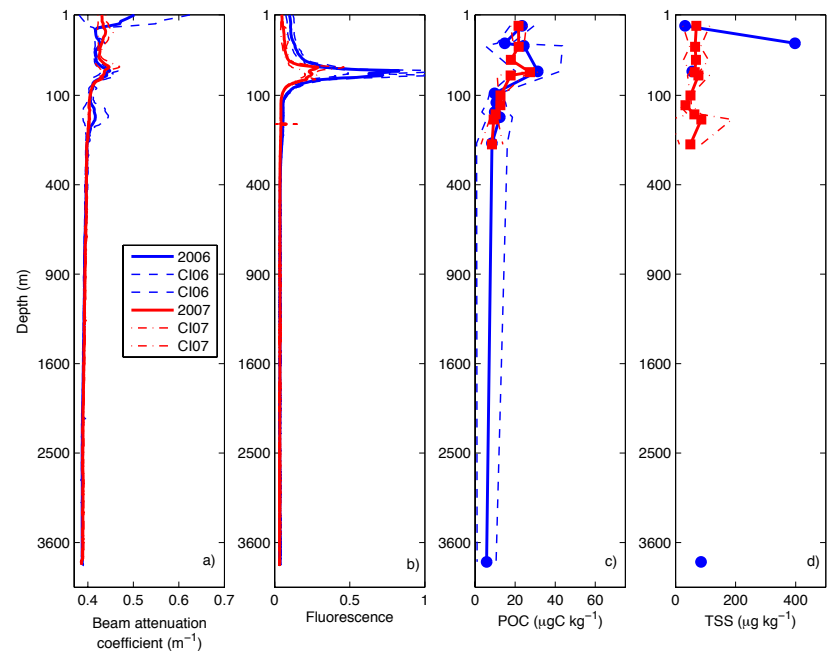

Fig. 5. As in Fig. 2 but for the interior of the Canada Basin. The upper $3800 \mathrm{~m}$ are shown to include all attenuation features and bottle samples. The scales on the horizontal axes are half of those in Figs. 2-3.
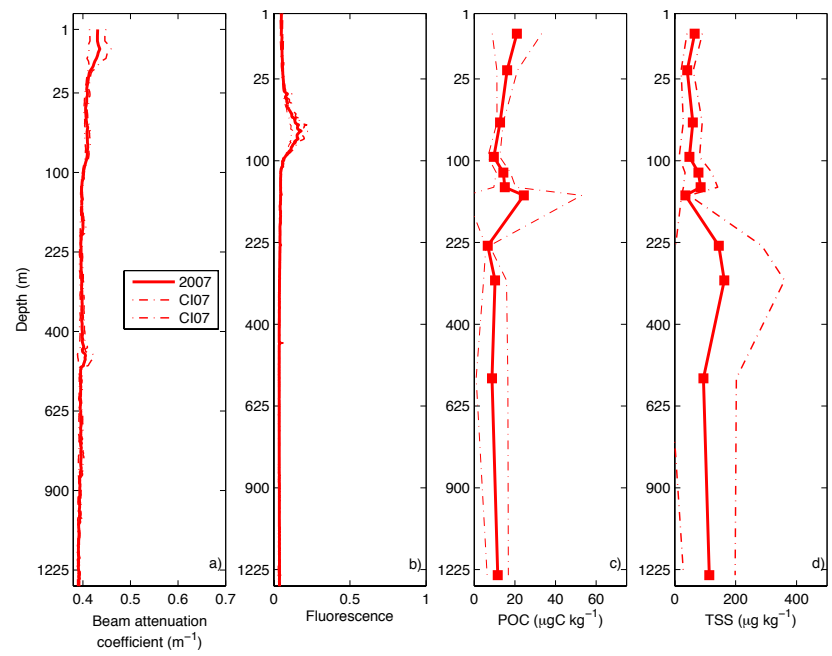

Fig. 6. As in Fig. 2 but for the eastern shelf of the Canada Basin. The upper $1300 \mathrm{~m}$ are shown to include all attenuation features and bottle samples. This region was sampled only in 2007. The scales on the horizontal axes are half of those in Figs. 2-3.

the particles at $20 \mathrm{~m}$ were primarily inorganic and were released from melting sea ice, then trapped within the strong summer halocline that formed as the ice melted. The attenuation maximum in this region had high-fluorescence, high POC, and was at a depth of about $50 \mathrm{~m}$. This deep chlorophyll maximum had much higher fluorescence values in 2006 than 2007, however the average POC (with 95\% confidence interval) was $64 \pm 22 \mu \mathrm{gC} \mathrm{kg}^{-1}$ in 2006 and $47 \pm 8 \mu \mathrm{gC} \mathrm{kg}-1$ in 2007 , so there was no apparent statistical difference in POC concentrations. 


\subsection{The interior of the Canada Basin}

Similar to the Northwind Ridge, the main attenuation features in the Basin region were observed in the near-surface waters (Fig. 5). A non-fluorescent attenuation feature that had relatively high POC was observed at the surface in 2006 and at about $10 \mathrm{~m}$ in 2007 . There was considerable sea ice melt during our sampling in both years, thus the particles observed in the upper $10 \mathrm{~m}$ could have been recently deposited from the melting ice and trapped in the surface summer halocline. The highest attenuation was the deep chlorophyll maximum at about $50 \mathrm{~m}$. Similar to the Northwind Ridge, fluorescence (but not POC) was greater in 2006 than 2007. The average POC concentrations (with $95 \%$ confidence intervals) were $31 \pm 11 \mu \mathrm{gC} \mathrm{kg}^{-1}$ in 2006 and $27 \pm 4 \mu \mathrm{gC} \mathrm{kg}^{-1}$ in 2007, which is lower than the values found near the Northwind Ridge but about double those found in the central Basin in April and May by Kinney et al. (1971) and Gordon and Cranford (1985). An anomalous attenuation feature was observed at a depth of about $150 \mathrm{~m}$ within PWW (salinity = 33.1 ) in 2006 that was correlated with slightly higher POC values. Although not apparent in the attenuation profile, the highest average TSS concentrations were also observed within PWW in 2007. These results suggest that some particles are transported into the basin within PWW.

\subsection{The eastern shelf of the Canada Basin}

The eastern shelf region was sampled only in 2007 because this region is usually inaccessible due to ice thickness. A general observation of this area was that the attenuation, fluorescence, POC and TSS concentrations in the upper $100 \mathrm{~m}$ were lower than in any other non-basin region (Fig. 6). Overall, four attenuation features were observed. These were (i) The attenuation maximum, which was located at the surface and had low fluorescence and relatively high POC concentrations; (ii) The fluorescence maximum that was at a depth of about $60 \mathrm{~m}$. Here, both the fluorescence and POC were much lower than other shelf-slope regions, suggesting that this is one of the least productive areas of the Canada Basin; iii) An attenuation feature at about $200 \mathrm{~m}$ that was above the TSS maximum. This feature is difficult to see in Fig. 6a and is more obvious in the individual station profile (not included). The TSS maximum was centred at $129.2^{\circ} \mathrm{W}$ and was observed from about 320-370 m, within the salinity range 34.74-34.78. This feature had the highest observed TSS concentration of the region $\left(263 \mu \mathrm{g} \mathrm{kg}^{-1}\right)$, and given the slightly tilted isopycnals (not shown), could be from resuspension due to the passage of a boundary current transporting Atlantic water. It is interesting to note that there was a TSS peak at the salinity 32.9 and a POC peak at the salinity 33.1 that were not observed in the attenuation profiles. (iv) The fourth feature was within the salinity range 34.82-34.86 from $446 \mathrm{~m}$ to the bottom (492 m) and suggest the presence of a bottom nepheloid layer at the $500 \mathrm{~m}$ depth station.

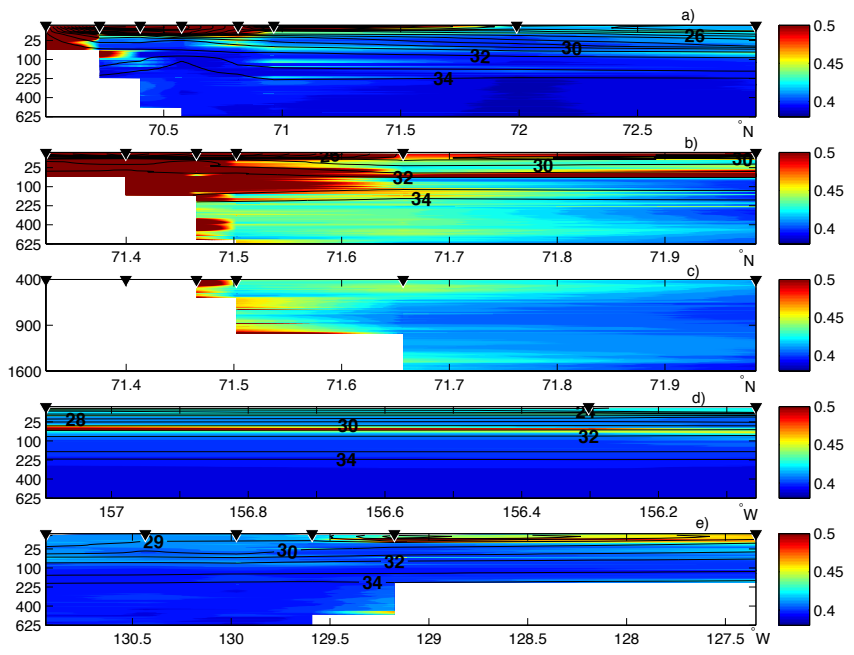

Fig. 7. A comparison of the beam attenuation coefficient $\left(\mathrm{m}^{-1}\right)$ along four different shelf-basin sections. All data are from the summer of 2007. These are (a) the eastern Beaufort shelf region along the longitude $140^{\circ} \mathrm{W}$, (b) the western Beaufort shelf region along the longitude $150-152^{\circ} \mathrm{W}$. Here, the near-surface (1-625 m) attenuation features are shown (c) The deep attenuation features (400$1600 \mathrm{~m}$ ) along the western Beaufort shelf, (d) The eastern Northwind Ridge slope region along the latitude $75-76^{\circ} \mathrm{N}$, and (e) the eastern shelf of the Canada Basin region along the latitude 73 $74^{\circ} \mathrm{N}$. The vertical axis is nonlinear (square root). Black horizontal lines represent the isohalines with 1.0 salinity resolution and black triangles denote the station locations.

\subsection{Attenuation from the shelf to the basin}

Our results showed that there were several profiles along the continental slope that had high attenuation either along the bottom as nepheloid layers or in the water column within different water masses. To compare these features among regions, we contoured attenuation from shelf to basin for the eastern Beaufort shelf region, the western Beaufort shelf region, the eastern Northwind Ridge slope region and the eastern shelf of the Canada Basin region in 2007 (Fig. 7). In the eastern Beaufort shelf region, most of the particles were observed at the surface and there was a small nepheloid layer along the slope. Overall, the western Beaufort shelf region had the highest attenuation below $100 \mathrm{~m}$. Here, we found that particles at about $400 \mathrm{~m}$ (salinity 34.83 ) and $1500 \mathrm{~m}$ (salinity 34.92) extended to at least $72^{\circ} \mathrm{N}$ in the basin. The lowest attenuation below $100 \mathrm{~m}$ was seen at the Northwind Ridge and no nepheloid layer was found. Along the eastern shelf, we found the highest attenuation along the slope after the western Beaufort shelf, suggesting the presence of a significant nepheloid layer to about $800 \mathrm{~m}$.

Results from the attenuation, fluorescence, POC and TSS data collected during the summers of 2006 and 2007 indicate six relatively consistent attenuation features and several 
irregular attenuation features in the Canada Basin. The six main features were found within (i) surface water, (ii) the summer halocline, (iii) water that has high fluorescence, (iv) cold water within the salinity range 32.9-33.1 of Pacific Winter Water, (v) Atlantic water within the salinity range 34.4-34.85, and (vii) samples taken at the bottom. Of these features, only the first three were found in the basin region and were generally at depths less than $70 \mathrm{~m}$. These nearsurface features can had both high POC and TSS concentrations. All six features were found at various locations on the shelves and slopes surrounding the Canada Basin and generally had high TSS concentrations. Thus, particle concentrations within the Canada Basin have significant spatial variability.

\section{Interannual variation of beam attenuation coefficient and fluorescence from 2003 through 2008}

Here, we examine the interannual variation of beam attenuation coefficient and fluorescence within the six consistent attenuation features in the eastern and western Beaufort shelf, along the eastern slope of the Northwind Ridge, and in the interior of the Canada Basin from 2003 to 2008.

\subsection{The eastern Beaufort shelf}

Similar to our 2006 and 2007 analysis, we found that the greatest attenuation in the eastern Beaufort shelf was near the coast and at the surface (Fig. 8). At the surface, attenuation was highest (up to $1.5 \mathrm{~m}^{-1}$ ) at $70.5^{\circ} \mathrm{N}$ in 2006 . Surface waters in this region during these cruises were found to have a high fraction of runoff from the Mackenzie River (Yamamoto-Kawai et al., 2009; Guay et al., 2009) and the attenuation variability again emphasizes the inconsistent location of the Mackenzie River plume and its changing particle load. The summer halocline was indistinguishable from Mackenzie River water, thus we could not compare attenuation within the summer halocline. Water that had high fluorescence was observed both on the shelf and within the subsurface chlorophyll maximum. The highest shelf fluorescence values (with chlorophyll $a$ estimates up to $5 \mu \mathrm{g} \mathrm{L}^{-1}$ at $15-25 \mathrm{~m}$ ) were seen at $70^{\circ} \mathrm{N}$ in 2007 while the highest subsurface chlorophyll values $\left(0.65 \mu \mathrm{g} \mathrm{L}^{-1}\right.$ at $\left.55-60 \mathrm{~m}\right)$ were seen at $72^{\circ} \mathrm{N}$ in 2006. The fluorescence values were lowest in 2008 throughout the region (not shown). High attenuation was observed within cold (temperature range -1.4 to $-1.7^{\circ} \mathrm{C}$ ) water in the salinity range $32.9-33.2$ in 2005 , 2006 and 2008 , with highest values $\left(0.55 \mathrm{~m}^{-1}\right.$ at $\left.133 \mathrm{~m}\right)$ in 2008. Melling and Lewis (1982) found that cold, dense water is formed along the Beaufort shelf in winter that descends into the Canada Basin, thus, these high attenuation plumes could be Beaufort shelf-derived winter water instead of PWW. There were several high attenuation features within Atlantic water and these were especially evident in 2005 to

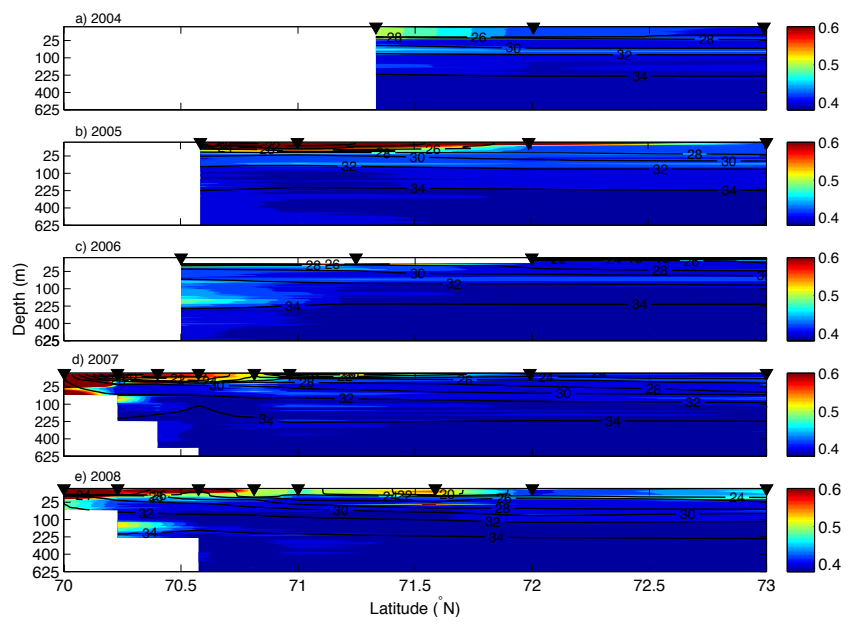

Fig. 8. An interannual comparison of beam attenuation coefficient (in $\mathrm{m}^{-1}$ ) from a section along the longitude $140^{\circ} \mathrm{W}$ in the eastern Beaufort shelf region for the years (a) 2004, (b) 2005, (c) 2006, (d) 2007, and (e) 2008. This section was not sampled in 2003. Here, the vertical axis is nonlinear (square root) to emphasize the near-surface features. The black lines show isohalines at 2 salinity unit intervals. The black triangles represent station locations for each year. Note that the attenuation range is about double that in Fig. 7.

2007. These features could be nepheloid layers, however, the isohalines in 2007 suggest upwelling near the shelf so the 2007 attenuation could have been due to particles entrained into Atlantic water from resuspension.

\subsection{The western Beaufort shelf}

In the western Beaufort shelf region, much of the attenuation variability was observed near the shelf and in subsurface plumes that appear to extend into the Canada Basin (Fig. 9). Similar to the eastern Beaufort shelf, the highest attenuation at the surface (up to $1.4 \mathrm{~m}^{-1}$ at $71.4^{\circ} \mathrm{N}$ ) was in 2006. This high surface attenuation in 2006 was correlated with high POC (see Sect. 3.2) and fluorescence (chlorophyll $a$ estimates up to $3.9 \mu \mathrm{g} \mathrm{L}-1$ at $22 \mathrm{~m}$ ), which indicates that attenuation was mainly due to phytoplankton. Surface attenuation was lowest in 2003. Due to the high fraction of sea ice meltwater and meteoric water, with sources likely from Russian Rivers (Yamamoto-Kawai et al., 2009), it was difficult to discern surface waters from the summer halocline. The subsurface chlorophyll maximum had the highest values in 2007 with chlorophyll $a$ estimates up to $4.8 \mu \mathrm{g} \mathrm{L}^{-1}$ at $52 \mathrm{~m}$ at $72^{\circ} \mathrm{N}$. Several high attenuation plumes were evident in waters with salinity greater than 32.5. The most obvious was the cold core eddy in 2006 (with a maximum attenuation value of $0.67 \mathrm{~m}^{-1}$ at $157 \mathrm{~m}$ ) that had high POC concentrations (discussed in Sect. 3.2). Other high attenuation layers were observed at $400 \mathrm{~m}$ in 2005 with maximum 


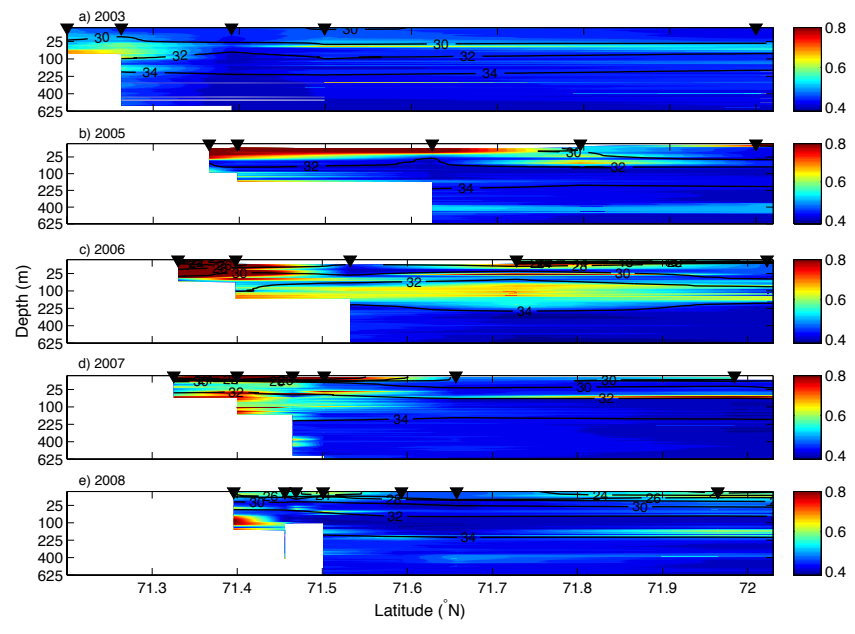

Fig. 9. As in Fig. 8 but for the western Beaufort shelf region for the years (a) 2003, (b) 2005, (c) 2006, (d) 2007, and (e) 2008. This section was not sampled in 2004. Note that the attenuation range is about double what it was in Fig. 8.

attenuation of $0.54 \mathrm{~m}^{-1}$ at the salinity 34.82 and at $162 \mathrm{~m}$ in 2008 with maximum attenuation of $0.62 \mathrm{~m}^{-1}$ at the salinity 33.3. There was evidence of a bottom nepheloid layer, particularly in 2007 and 2008.

\subsection{The eastern Northwind Ridge slope region}

The summer cruises over the Northwind region sampled both a southern (latitudes $75-76^{\circ} \mathrm{N}$ ) and a northern (latitude 78$78.5^{\circ} \mathrm{N}$ ) section (see Fig. 1) so we contoured these sections separately (Fig. 10). During our study, high attenuation was seen near the surface that could have been due to particles deposited from melting ice. Unlike the basin region, the summer halocline was weaker here and the high attenuation was spread throughout the upper $25 \mathrm{~m}$, suggesting that particles did not accumulate in the strong stratification. In the surface waters, attenuation was highest (with a maximum attenuation of $0.45 \mathrm{~m}^{-1}$ at $2 \mathrm{~m}$ ) along the northern line in 2005 . High attenuation within the summer halocline was most prevalent in the southern section in 2006. The predominant feature along the Northwind Ridge was the subsurface chlorophyll maximum. We found that fluorescence was higher along the southern Northwind Ridge, with the highest estimated chlorophyll $a$ value of $3.4 \mu \mathrm{g} \mathrm{L}^{-1}$ at $52 \mathrm{~m}$ in the southern region in 2006. Below $100 \mathrm{~m}$, there was little interannual variability, however, the attenuation here was higher than either the basin interior or eastern shelf regions. This indicates that particles could be transported from the Chukchi Sea to Northwind Ridge in deeper waters, as was suggested by Nishino et al. (2008).

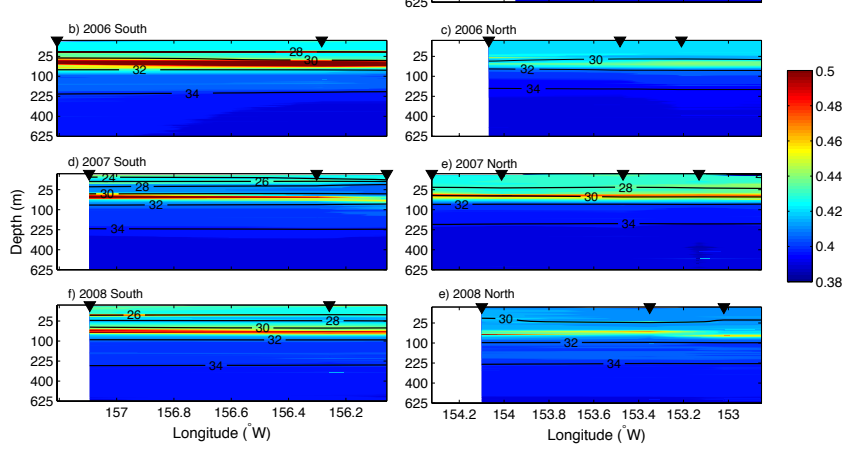

Fig. 10. As in Fig. 8 but for the eastern Northwind Region slope region. This region was sampled along a southern line (latitudes $75-76^{\circ} \mathrm{N}$ ) and along a northern line (latitudes $78-79^{\circ} \mathrm{N}$ ). Here, the northern line is shown on the right for (a) 2005, (c) 2006, (e) 2007, and (g) 2008 and the southern line is shown on the right for b) 2006 , (d) 2007, and (f) 2008. Only one station was sampled along each line in 2003, 2004 and the southern region in 2005. The attenuation range is about half what it is in Fig. 8.

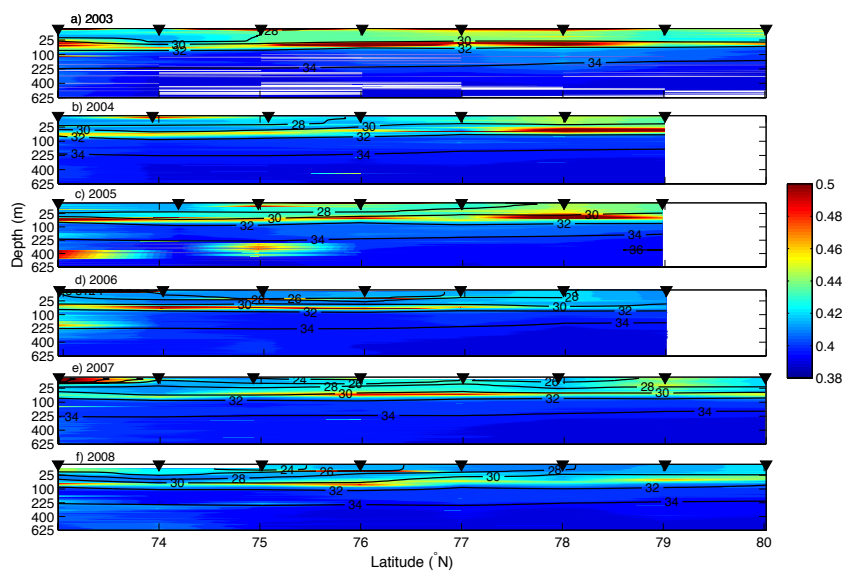

Fig. 11. As in Fig. 8 but for the interior of the Canada Basin for the years (a) 2003, (b) 2004, (c) 2005, (d) 2006, (e) 2007, and (f) 2008. These stations were located along the $150^{\circ} \mathrm{W}$ section, which is a continuation of the western Beaufort shelf section. Note that the attenuation range is about half what it was in Fig. 8.

\subsection{The interior of the Canada Basin}

Most of the variability along $150^{\circ} \mathrm{W}$ within the Canada Basin was observed in the upper $100 \mathrm{~m}$ and near the southern end (Fig. 11). At the surface, attenuation was highest from 2003 to 2005 , particularly north of $75^{\circ} \mathrm{N}$. From 2006 to 2008, although not obvious in Fig. 11, attenuation was higher in the summer halocline and lower at the surface. This suggests that the strengthened summer halocline from 2006 to 


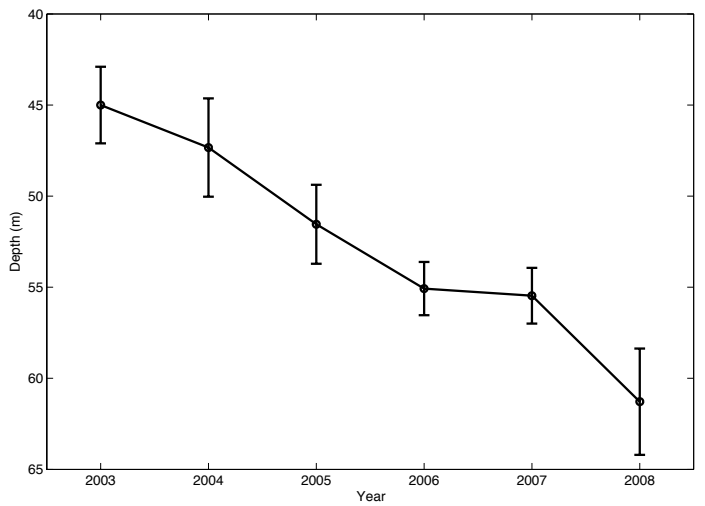

Fig. 12. The average depth (with standard error bars) of the subsurface chlorophyll maximum in the interior of the Canada Basin from 2003 to 2008 . Here, only stations that had a bottom depth greater than $3500 \mathrm{~m}$ and were along the $140^{\circ} \mathrm{W}$ or $150^{\circ} \mathrm{W}$ section within the latitudes $73^{\circ}-80^{\circ} \mathrm{N}$ were used to calculate the average. The number of stations that fit these criteria was 11 in 2003, 12 in 2004, 11 in 2005, 13 in 2006, 15 in 2007, and 14 in 2008.

2008 (Jackson et al., 2010) trapped suspended particles that may have otherwise descended into the basin. The chlorophyll maximum was variable, with the highest chlorophyll $a$ estimate of $3.3 \mu \mathrm{g} \mathrm{L}^{-1}$ at $60 \mathrm{~m}$ in 2006 . The chlorophyll maximum also appeared to deepen over our study period. To elucidate this trend, the average depth of the chlorophyll maximum was calculated at basin stations (i.e. bottom depth greater than $3500 \mathrm{~m}$ ) along the $140^{\circ} \mathrm{W}$ and $150^{\circ} \mathrm{W}$ section lines (Fig. 12). We found that the subsurface chlorophyll maximum deepened at a rate of $3.2 \mathrm{~m}$ per year from an average of $45 \mathrm{~m}$ in 2003 to an average of $61 \mathrm{~m}$ in 2008, with the greatest difference observed between 2007 and 2008 . The deepening of the chlorophyll maximum could be caused by two different processes. The first is that the decreased summer sea ice cover has allowed photosynthetically active radiation to penetrate deeper and phytoplankton have been able to utilize nutrients at deeper depths. The second is that the nutricline itself has descended. Understanding why the chlorophyll maximum has deepened is an important area of future research since the first process would cause primary production to increase while the second would cause it to decrease. Below $100 \mathrm{~m}$, attenuation features were observed at the southern end of the section. In particular, high attenuation was observed at $73^{\circ} \mathrm{N}$ in 2005 (with values up to $0.50 \mathrm{~m}^{-1}$ ) from about $350-430 \mathrm{~m}$ within the salinity range 34.76 to 34.81 and in 2006 (with values up to $0.48 \mathrm{~m}^{-1}$ ) from about $150-200 \mathrm{~m}$ within the salinity range 33 to 33.5 . These regions of high attenuation have the same properties as the subsurface plumes observed in the western Beaufort shelf region (Sect. 4.2) and suggest that particles can be transported as far as $150 \mathrm{~km}$ from the shelf into the basin.
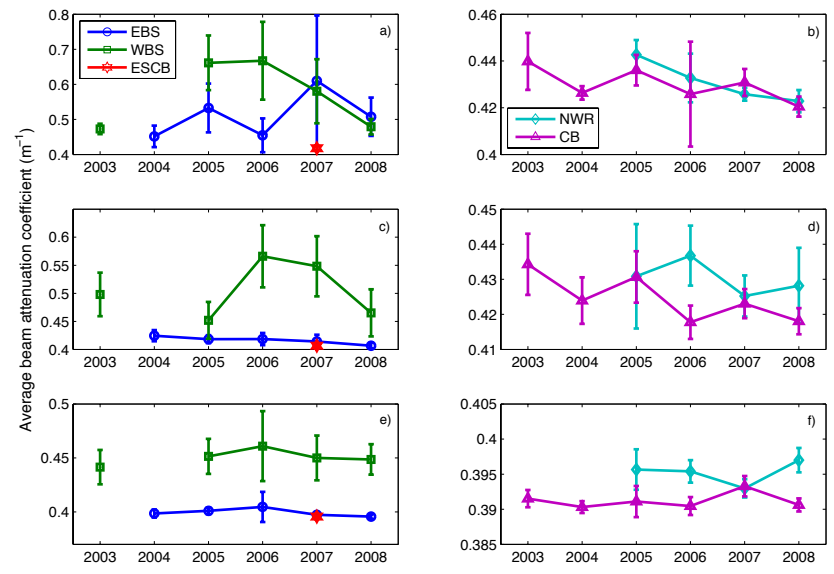

Fig. 13. The average attenuation within the five different regions the eastern Beaufort shelf (EBS), the western Beaufort shelf (WBS), the eastern shelf of the Canada Basin (ESCB), the eastern slope of the Northwind Ridge (NWR) and the interior of the Canada Basin (CB). The error bars represent the standard error. The average attenuation was plotted for shelf stations EBS, WBS and ESCB (a, c and $\mathbf{e}$ ) and basin stations NWR and CB (b, $\mathbf{d}$ and $\mathbf{f})$. To understand how attenuation varied with depth, the average was calculated for a and b) $1-25 \mathrm{~m}$, c and d) $26-100 \mathrm{~m}$, and e) $101-500 \mathrm{~m}$ for the shelf stations and f) $101-900 \mathrm{~m}$ for NWR and $101-3500 \mathrm{~m}$ for CB.

To examine whether attenuation has changed from 2003 to 2008, attenuation was averaged each year for all stations within each region (Fig. 13). The water column was separated into three layers to see if there were any changes near the surface $(1-25 \mathrm{~m})$, in waters that contain the subsurface chlorophyll maximum $(26-100 \mathrm{~m})$ and in deeper waters (101-500 $\mathrm{m}$ for the eastern and western Beaufort shelf and the east shelf of the Canada Basin, 101-900 m for the Northwind Ridge and 101-3500 $\mathrm{m}$ for the interior of the Canada Basin). There are several conclusions that can be drawn from this figure, (i) With the exception of the surface layer in 2007 and 2008, attenuation was always highest in the western Beaufort shelf, (ii) In the intermediate and deeper layers, attenuation was generally higher in the Northwind Ridge than the interior of the Canada Basin, (iii) Attenuation in the surface layer may have decreased at the Northwind Ridge from 2005-08, however the high standard error made the trend not statistically significant, and (iv) Attenuation may have decreased over the study period in the intermediate layer at the eastern Beaufort shelf and in the interior of the Canada Basin but the high standard error again made the trends not statistically significant. Thus we conclude that attenuation did not increase during our study period as was suggested by Carmack et al. (2006). 

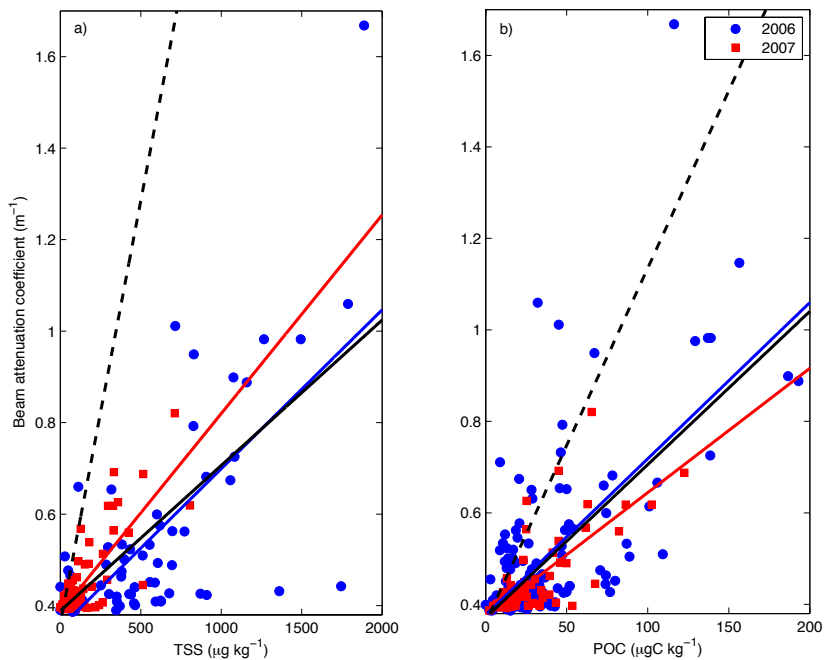

Fig. 14. Linear least squares regression of (a) the relationship between beam attenuation coefficient and total suspended solids, and (b) the relationship between beam attenuation coefficient and particulate organic carbon. The blue dots represent samples taken in 2006 and the red squares are samples taken in 2007. The blue and red lines represent the line of best fit for 2006 and 2007, respectively. The solid black line represents the line of best fit from both years together and the dashed black line represents the linear regression $(\mathrm{bac}=0.00755(\mathrm{POC})+0.36$ and $\mathrm{bac}=0.00185(\mathrm{TSS})+0.36)$ from Bishop (1999) based on JGOFS Equatorial Pacific data.

\section{Correlation between attenuation and POC and TSS}

One of the main objectives of this project was to determine whether a relationship between transmission and POC and transmission and TSS exists in the Canada Basin. Our overall attenuation and TSS relationship (Fig. 14a and Table $1, R^{2}=0.54$ ) was less-correlated than observed in the Gulf Stream and Sargasso Sea $\left(R^{2}=0.76-0.89\right.$; Bishop, 1986), in Puget Sound $\left(R^{2}=0.78-0.90\right.$; Baker and Lavelle, 1984), along the continental rise of the northwest Atlantic $\left(R^{2}=0.97-0.98\right.$; Gardner et al., 1985), in the Equatorial Pacific $\left(R^{2}=0.60-0.91\right.$; Bishop, 1999), and in the Laptev Sea near the Lena River delta $\left(R^{2}=0.96\right.$; Burenkov, 1993). Our attenuation and POC relationship (Fig. 14b and Table 2, $\left.R^{2}=0.48\right)$ was less-correlated than observed in the Equatorial Pacific $\left(R^{2}=0.75-0.95\right.$; Bishop, 1999) and sub-arctic Pacific $\left(R^{2}=0.95\right.$; Bishop et al., 1999) when POC was sampled with a Multiple Unit Large Volume in situ Filtration System but better correlated than when POC was sampled in the Equatorial Pacific using rosette bottles $\left(R^{2}=0.41\right.$; Bishop, 1999). In addition, the slope of the line of best fit for our samples was less steep than observed by Bishop (1999) in the Equatorial Pacific, suggesting that the particles in the Canada Basin are both heavier and less efficient at scattering light. We also compared the correlation in 2006 and 2007 and found that in general both TSS $\left(R^{2}=0.64\right)$
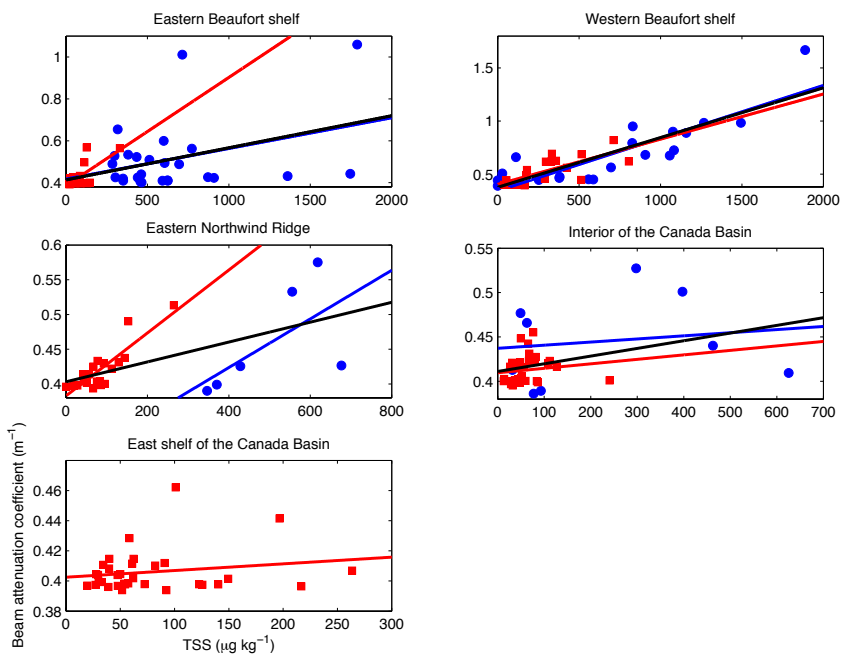

Fig. 15. Linear regression of the relationship between beam attenuation coefficient and total suspended solids $\left(\mu \mathrm{gkg}^{-1}\right)$ in the five different regions. Here, the blue circles are samples from 2006 and the red squares are from 2007. The lines denote the linear least square regression from 2006 (blue lines), 2007 (red lines) and both 2006 and 2007 (black lines). Linear relations and $R^{2}$ values are listed in Table 1. Note that the scales are different in each figure.

and POC $\left(R^{2}=0.58\right)$ were more correlated with attenuation in 2007 than in 2006. The relatively poor correlation in the Canada Basin and its surrounding shelves could be caused by (i) scatter due to hydrographic variability (Bishop et al., 1999); (ii) the use of rosette bottles instead of large volume pumps to collect POC and TSS samples (Bishop, 1999), although Gardner et al. (2003) suggest the bottle sampling method is better in polar oceans; (iii) an inconsistent particle size (Kitchen et al., 1982; Boss et al., 2001; Bowers et al., 2009), particle composition (Kitchen et al., 1982), or particle density (Bowers et al., 2009); or (iv) increased absorption of coloured dissolved organic material in the Arctic Ocean (Pegau, 2002) compared to other regions, which could affect attenuation.

To determine the effect of hydrographic variability on the relationship between attenuation and TSS and POC concentrations, we separated the data into the five different regions. For TSS, we found that there was significant variability between these regions (Fig. 15, Table 1). Part of this variability was because TSS concentrations were much higher in 2006 than 2007. Overall, the best fits were observed in the western Beaufort shelf in 2006 and in the Northwind Ridge in 2007. The worst fits were seen within the Basin and on the eastern shelf.

Examining each region separately, we found that in the eastern Beaufort shelf, most of the outlier points were observed at $5 \mathrm{~m}$. We removed these outliers but the correlation worsened $\left(R^{2}=0.13\right)$. An assessment of particles measured in sediment traps offshore of the Mackenzie River showed 
Table 1. A comparison of the relationships between beam attenuation coefficient and total suspended solids. The symbol $n$ represents the number of samples in each linear regression. The units for slope and intercept are $\mathrm{m}^{-1}\left(\mu \mathrm{gkg}^{-1}\right)^{-1}$ and $\mathrm{m}^{-1}$, respectively.

\begin{tabular}{clcccc}
\hline Region & year & $n$ & slope $($ x 10 & intercept & $R^{2}$ \\
\hline all & 2006 & 62 & 0.347 & 0.35 & 0.44 \\
& 2007 & 130 & 0.434 & 0.39 & 0.64 \\
& 2006,2007 & 295 & 0.318 & 0.39 & 0.54 \\
Eastern & 2006 & 26 & 0.147 & 0.42 & 0.13 \\
Beaufort & 2007 & 22 & 0.517 & 0.39 & 0.47 \\
& 2006,2007 & 48 & 0.153 & 0.41 & 0.23 \\
Western & 2006 & 21 & 0.496 & 0.34 & 0.75 \\
Beaufort & 2007 & 20 & 0.425 & 0.40 & 0.56 \\
& 2006,2007 & 41 & 0.468 & 0.38 & 0.75 \\
Northwind & 2006 & 6 & 0.350 & 0.28 & 0.39 \\
Ridge & 2007 & 19 & 0.453 & 0.38 & 0.74 \\
& 2006,2007 & 25 & 0.143 & 0.40 & 0.36 \\
Canada & 2006 & 9 & 0.035 & 0.44 & 0.02 \\
Basin & 2007 & 35 & 0.050 & 0.41 & 0.02 \\
& 2006,2007 & 44 & 0.087 & 0.41 & 0.14 \\
East shelf & 2007 & 33 & 0.044 & 0.40 & 0.03 \\
\hline
\end{tabular}

Table 2. A comparison of the relationships between beam attenuation coefficient and particulate organic carbon. The symbol $n$ represents the number of samples in each linear regression. The units for slope and intercept $\operatorname{are~}^{-1}\left(\mu g \mathrm{~kg}^{-1}\right)^{-1}$ and $\mathrm{m}^{-1}$, respectively.

\begin{tabular}{clcccc}
\hline Region & year & $n$ & slope $($ x 10 & intercept & $R^{2}$ \\
\hline all & 2006 & 174 & 0.341 & 0.38 & 0.45 \\
& 2007 & 121 & 0.272 & 0.37 & 0.58 \\
& 2006,2007 & 295 & 0.335 & 0.37 & 0.48 \\
Eastern & 2006 & 63 & 0.235 & 0.41 & 0.11 \\
Beaufort & 2007 & 23 & 0.216 & 0.38 & 0.30 \\
& 2006,2007 & 86 & 0.238 & 0.40 & 0.12 \\
Western & 2006 & 37 & 0.320 & 0.43 & 0.44 \\
Beaufort & 2007 & 20 & 0.254 & 0.41 & 0.46 \\
& 2006,2007 & 57 & 0.314 & 0.46 & 0.41 \\
Northwind & 2006 & 27 & 0.152 & 0.37 & 0.37 \\
Ridge & 2007 & 20 & 0.19 & 0.38 & 0.59 \\
& 2006,2007 & 47 & 0.14 & 0.38 & 0.39 \\
Canada & 2006 & 47 & 0.142 & 0.39 & 0.32 \\
Basin & 2007 & 29 & 0.206 & 0.38 & 0.75 \\
& 2006,2007 & 76 & 0.152 & 0.39 & 0.37 \\
East shelf & 2007 & 32 & 0.166 & 0.38 & 0.52 \\
\hline
\end{tabular}

substantial compositional diversity (O'Brien et al., 2006). The transmissometer gives the most accurate readings when the particles are small and have a low density (Bowers et al., 2009) so we suggest that some of the variability in our TSS and attenuation correlation is from inconsistent particle size and composition. Thus, the eastern Beaufort shelf is not a good candidate for finding a linear relationship between TSS and attenuation. Along the western Beaufort shelf, the relationship was best in 2006, even in the shallow shelf stations. This suggests that the particles in the western Beaufort shelf are small and of low density and the relationship found in this area can be used to estimate past TSS con- centrations. There was significant interannual variability at the Northwind Ridge, with much higher TSS concentrations observed in 2006. However, TSS was well-correlated with attenuation in 2007 when more data points were available, thus we attribute some of the interannual variability to insufficient sampling in 2006. In the interior of the Canada Basin, the outlying points could be placed into 3 groups (i) Those with high TSS concentrations and low attenuation. These were found either near the surface in the southern basin or near the bottom; (ii) Those with high TSS concentrations and high attenuation. These were found above $20 \mathrm{~m}$ in the southcentral basin; (iii) Those with low TSS concentrations and 

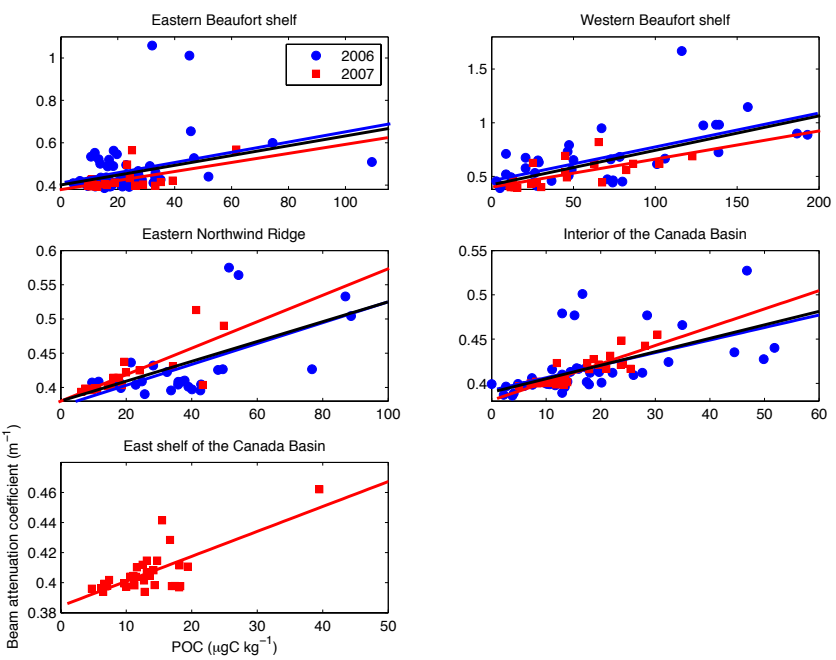

Fig. 16. As in Fig. 9 but for correlations between attenuation and POC. Linear relations and $R^{2}$ values are listed in Table 2. Note that the scales are different in each figure.

high attenuation. These were all found at the deep chlorophyll maximum throughout the basin. Similar to Bishop (1999), our results suggest that the transmissometer does not linearly represent TSS and it is likely that the attenuation values depend on the percentage of organic matter. Along the eastern shelf of the basin, we found that there were two types of outlying points (i) those with high TSS concentrations and low attenuation, found in water below $100 \mathrm{~m}$; (ii) those with high TSS concentrations and high attenuation, found primarily at $5 \mathrm{~m}$. Unlike the interior of the basin, there were no low TSS, high attenuation particles found within the deep chlorophyll maximum and this is likely because the chlorophyll concentrations (and thus POC) were very low here. From these evaluations, we suggest that a reasonable relationship between TSS and attenuation can only be found in the western Beaufort shelf region.

We also ran linear regressions to determine the relationship between attenuation and POC within each region (Fig. 16, Table 2). We found the best relationship within the basin and on Northwind Ridge in 2007, confirming results from Bishop (1999) who found that attenuation was much better correlated with POC than TSS in open ocean areas. POC and attenuation were least correlated along the eastern Beaufort shelf.

An examination of the outliers in the eastern Beaufort shelf found that they were generally from samples that had high TSS concentrations. Thus, we conclude that the particle composition of the eastern Beaufort shelf is too variable to be represented by a linear relationship between POC and attenuation. In the western Beaufort shelf, attenuation and POC were well correlated below an attenuation of $1.1 \mathrm{~m}^{-1}$. When we removed the outlier at attenuation $1.6 \mathrm{~m}^{-1}$, the relationship for both 2006 and 2007 improved to $R^{2}=0.53$.
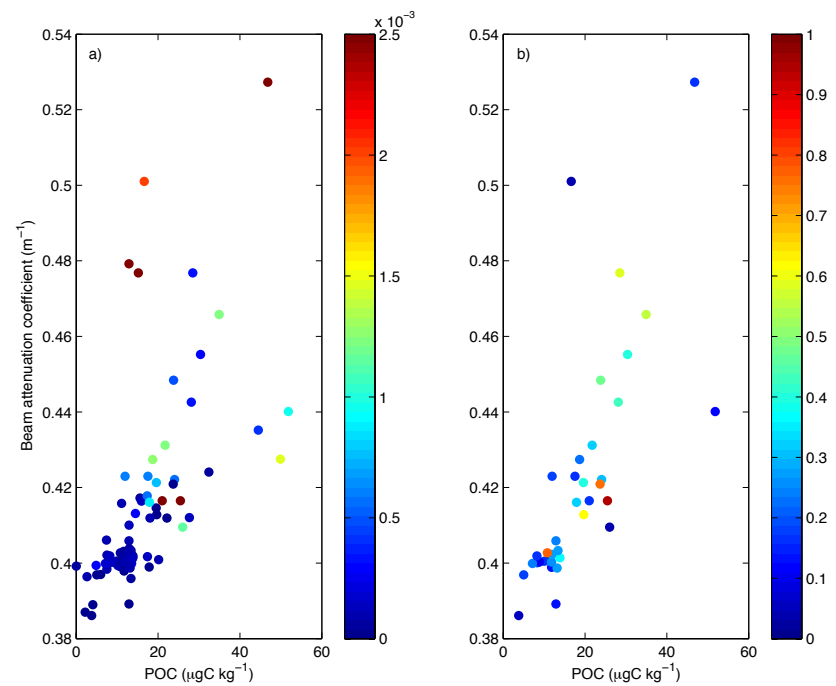

Fig. 17. Relationship for the stations within the interior of the Canada Basin between (a) attenuation and POC with the BruntVäisälä-frequency $\left(\mathrm{s}^{-1}\right)$ in colour and $(\mathbf{b})$ attenuation and $\mathrm{POC}$ with the ratio of POC to TSS in colour. There are fewer points in plot b) because TSS was sparsely sampled in 2006.

Within the basin, we found that many of the outliers were within the upper $20 \mathrm{~m}$, which corresponded to the summer halocline. To examine this relationship, we calculated first the Brunt-Väisälä-frequency as a measurement of stratification (Fig. 17a) and found that several of the high attenuation, low POC points were located within the highly stratified water of the summer halocline. We suggest these particles are deposited in the surface ocean when sea ice melts and are trapped by the strong stratification. Previous studies have found that, although there is considerable variability, most of the particles in sea ice are inorganic (Pfirman et al., 1989; Dethleff et al., 2000). Thus, we calculated the ratio of POC:TSS to confirm that the outliers within the summer halocline also had high TSS concentrations relative to POC (Fig. 17b). Although some particles within the summer halocline had a high POC:TSS ratio, much of the variability can be explained by removing all particles that were found in water with a Brunt-Väisälä-frequency greater than $0.001 \mathrm{~s}^{-1}$. The relationship improved to $R^{2}=0.59$. Along the Northwind Ridge, we noticed that there were several samples that had low attenuation and high POC concentrations. Upon closer examination, we found that these POC samples had very high blank values so may have been contaminated in the lab. This contamination would have only affected the three Northwind Ridge stations in 2006. Thus, we decided to base the correlation between POC and attenuation solely on the 2007 relationship. Unlike the stations in the basin, the summer halocline over the Northwind Ridge was not very stratified and there were fewer particles trapped in this layer. This is likely because there was less ice cover here than in 
Table 3. TSS-attenuation and POC-attenuation statistics for regions that had good relationships ( $R^{2}$ value greater than 0.50 for all samples) between the bottle and sensor data. The symbols WBS stand for western Beaufort shelf, NWR for Northwind Ridge, CB for the interior of

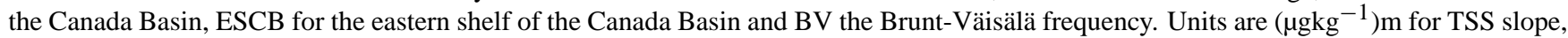
$\left(\mu \mathrm{g} \mathrm{kg}^{-1}\right) \mathrm{m}$ for POC slope, $\mu \mathrm{gkg}^{-1}$ for TSS intercept and $\mu \mathrm{gCkg}^{-1}$ for POC intercept. Note that the relationships are written in opposite direction to those in Tables 1 and 2 so that TSS and POC are calculated from beam attenuation coefficient.

\begin{tabular}{cccrccl}
\hline Particles & Region & Slope & Intercept & $R^{2}$ & RMSE & Comments \\
\hline TSS & WBS & 1595 & -472 & 0.75 & 233 & \\
POC & WBS & 188 & -55 & 0.53 & 33.1 & For attenuation $<1.1 \mathrm{~m}^{-1}$ \\
POC & NWR & 306 & -108 & 0.59 & 8.3 & \\
POC & CB & 410 & -153 & 0.59 & 6.1 & For water with $\mathrm{BV}<0.001 \mathrm{~s}^{-1}$ \\
POC & ESCB & 378 & -140 & 0.60 & 4.1 & Not for nepheloid layers \\
\hline
\end{tabular}

the basin region, so there was likely more mixing. Because of this, we decided that the POC-attenuation relationship was suitable for the entire water column. Along the eastern shelf of the Canada Basin, we found that the high attenuation, low POC outlier was found within the nepheloid layer at a depth of $500 \mathrm{~m}$. Since our data show that the nepheloid layer along the eastern shelf has low POC concentrations, we decided to exclude the nepheloid layer from our correlation. We defined the eastern shelf nepheloid layer as water within $50 \mathrm{~m}$ of the bottom along the slope (with bottom depths between about 250 and $3000 \mathrm{~m}$ ) that had attenuation higher than $0.43 \mathrm{~m}^{-1}$. Once this outlier was removed, the relationship improved to $R^{2}=0.60$.

We have defined one TSS-attenuation relationship and four POC-attenuation relationships that can be applied to attenuation profiles to estimate past TSS and POC concentrations (Table 3). Upon comparison of the observed to the estimated TSS and POC values, we found that the root mean square error was very high for both TSS and POC in the western Beaufort shelf. This is likely because despite a good linear correlation, the variable particle composition here did not allow for an accurate estimate of TSS and POC values. The method error estimates in the Northwind, basin and eastern shelf regions were all within the same order of magnitude of the average standard error for POC duplicates $\left(4.4 \mu \mathrm{gC} \mathrm{kg}^{-1}\right)$. Our POC estimates are also similar to previous studies. In the summer of 1994, Wheeler et al. (1997) sampled POC along a transect from the Chukchi Sea to the North Pole. They crossed the Canada, Makarov, Amundsen and Nansen Basins and found that there was an average of $4.6 \mathrm{gC} \mathrm{m}^{-2}$ in the upper $100 \mathrm{~m}$. These values were almost 5 times greater than the $1 \mathrm{gC} \mathrm{m}^{-2}$ that Kinney et al. (1971) and Gordon and Cranford (1985) found in April and May in the Canada Basin. To compare, we also integrated POC each year in the upper $100 \mathrm{~m}$ and, estimated that there was 2.1 to $2.6 \mathrm{gC} \mathrm{m}^{-2}$ in summer in the Canada Basin.

\section{Conclusions}

As the Arctic Ocean undergoes rapid change, one of the projected transitions is an increase in suspended particle concentrations (Carmack et al., 2006). For this paper, we examined suspended particle concentrations from both sensor (transmissometer and fluorometer) and bottle (POC and TSS) data from the summers of 2003 through 2008 to first locate regions of high attenuation, then to examine interannual variability within those regions, and finally to investigate whether simple linear relationships existed between TSS and attenuation, and POC and attenuation.

To account for spatial variability, we divided our study area into five regions. We observed the highest attenuation, TSS and POC concentrations along the Beaufort shelf. The eastern Beaufort shelf was characterized by high near-surface attenuation and POC and TSS concentrations and the particles were likely from the Mackenzie River. The western Beaufort shelf was more variable, with several attenuation features throughout the water column, including plumes that appeared to transport particles from the shelf up to $150 \mathrm{~km}$ north in the Canada Basin. Along the Northwind Ridge and within the Canada Basin, we observed that most of the particles were found above $100 \mathrm{~m}$ and were dominated by the subsurface chlorophyll maximum. The eastern shelf was the least productive region and had minimal fluorescence and POC values, however, a nepheloid layer at about 400 $900 \mathrm{~m}$ suggested the transport of particles from shelf into the Canada Basin.

Common attenuation features within the Canada Basin and its surrounding shelves were placed into six categories. These are (i) Particles in surface water; ii) Particles within the summer halocline. These particles are likely transported to the region in ice and deposited as the ice melts; (iii) Particles within high fluorescent water; (iv) Particles in the salinity range 32.9 to 33.1 that is either PWW or Beaufort shelfderived winter water. These are likely transported from the shelf into the basin through canyons or as eddies that are formed along the shelf; (v) Particles within Atlantic water in the salinity range $34.4-34.85$ that are likely deposited by 
resuspension due to upwelling or the passage of a boundary current; and (vi) Particles at the bottom that are often found within nepheloid layers.

In the interior of the Canada Basin, we found that the subsurface chlorophyll maximum deepened at a rate of $3.2 \mathrm{~m}$ per year from an average depth of $45 \mathrm{~m}$ in 2003 to $61 \mathrm{~m}$ in 2008 . This deepening could be the result of either increased photosynthetically available radiation (caused by the decreased summer sea ice cover) that would support phytoplankton at deeper depths or the deepening of the nutricline. Deeper light absorption would be expected to increase primary productivity while a deeper nutricline would decrease primary productivity. This is an important area of future research as these changes would be expected to have a significant impact on the Arctic Ocean ecosystem.

The annual differences in the average attenuation were calculated. We found that in all regions, most of the variability was above $100 \mathrm{~m}$. In general, the greatest attenuation was observed in the western Beaufort shelf. We found no evidence of increased attenuation from the summers of 2003 through 2008. Instead, there were examples where attenuation appeared to decrease over time - in the surface layer over the Northwind Ridge and in the intermediate layer (that includes the chlorophyll maximum) in both the eastern Beaufort shelf and in the interior of the chlorophyll maximum. These trends were not statistically significant because the standard error was high. We think that this work provides a baseline estimate of attenuation in the Canada Basin to which future changes can be compared.

One of the main goals of this paper was to find a relationship between attenuation and bottle (POC and TSS) data that could be applied to past transmissometer data. We found that there was no consistent relationship that could be applied to our entire study region so we again analyzed the five regions separately. In the eastern Beaufort shelf, we found that attenuation was not well-correlated with either POC or TSS and we suggest that the transmissometer cannot account for the particle variability in terms of both size and density. Along the western Beaufort shelf, both TSS and POC appeared to be well-correlated with attenuation, however, the error measurements were too high to be credible. Along the Northwind Ridge, within the basin and on the eastern shelf, POC and attenuation were well-correlated with the following exceptions - (i) Within the summer halocline in the interior of the Canada Basin. Here, it appears that both organic and inorganic particles are being trapped in the strong stratification so POC cannot be accurately estimated; (ii) Within the bottom nepheloid layer along the eastern shelf. Again, the particles here are primarily inorganic so POC cannot be estimated.
Acknowledgements. Ship based CTD, fluorescence, transmissometer and bottle measurements were supported by the Joint Western Climate Arctic Study (2003-6) and the Canadian International Polar Year Canada's Three Oceans project (2007-8). We acknowledge financial and ship time support from Fisheries and Oceans Canada, the National Sciences and Engineering Research Council of Canada, the Northern Scientific Research Program of Canada, Indian and Northern Affairs Canada, Arcticnet network of centres of excellence of Canada, the US National Science Foundation's Beaufort Gyre Exploration Project and collaboration with the Japan Agency for Marine-Earth Science and Technology. We deeply appreciate the assistance and support of the men and women of the Canadian Coast Guard icebreakers Louis S St Laurent for collecting CTD and bottle data, chief scientists S. Zimmerman, J. Eert and B. Van Hardenberg, and lab technicians Linda White and Maureen Soon.

Edited by: M. Hoppema

\section{References}

Ashjian, C. J., Gallager, S. M., and Plourde, S.: Transport of plankton and particles between the Chukchi and Beaufort Seas during summer 2002, described using a Video Plankton Recorder, DeepSea Res. Pt. II, 52, 3259-3280, 2005.

Baker, E. T. and Lavelle, J. W.: The effect of particle size on the the light attenuation coefficient of natural suspensions, J. Geophys. Res., 89, 8179-8203, 1984.

Bates, N. R., Hansell, D. A., Moran, S. B., and Codispoti L. A.: Seasonal and spatial distribution of particulate organic matter (POM) in the Chukchi and Beaufort Seas, Deep-Sea Res. Pt. II, 52, 3324-3343, 2005.

Bishop, J. K. B.: The correction and suspended particulate matter calibration of Sea Tech transmissometer data, Deep-Sea Res., 33(1), 121-134, 1986.

Bishop, J. K. B.: Transmissometer measurement of POC, Deep-Sea Res. Pt. I, 46, 353-369, 1999.

Bishop, J. K. B., Calvert, S. E., and Soon, M. Y. S.: Spatial and temporal variability of POC in the northeast Subarctic Pacific, Deep-Sea Res. Pt. II, 46, 2699-2733, 1999.

Boss, E., Twardowski, M. S., and Herring, S.: Shape of the particulate beam attenuation spectrum and its inversion to obtain the shape of the particulate size distribution, Appl. Opt., 40, 48854893, 2001.

Bowers, D. G., Braithwaite, K. M., Nimmo-Smith, W. A. M., and Graham, G. W.: Light scattering by particles suspended in the sea: The role of particle size and density, Cont.-Shelf Res., 29, 1748-1755, 2009.

Burenkov, V. I.: Optical properties of the Laptev Sea near the Lena River delta, in: Underwater Light Measurements, 2048, edited by: Eilertsen, H. C., The Society of Photo-Optical Instrumentation Engineers Proceedings Series, Bellingham Washington, USA, 175-183, 1993.

Carmack, E., Barber, D., Christensen, J., Macdonald, R., Rudels, B., and Sakshaug, E.: Climate variability and physical forcing of the food webs and the carbon budget on panarctic shelves, Prog. Oceanogr. 71, 145-181, 2006. 
Codispoti, L. A., Flagg, C., Kelly, V., and Swift, J. H.: Hydrographic conditions during the 2002 SBI process experiments, Deep-Sea Res. Pt. I, 52, 3199-3226, 2005.

Darby, D. A.: Sources of sediment found in sea ice from the western Arctic Ocean, new insights into processes of entrainment and drift patterns, J. Geophys. Res., 108, C8, doi:10.1029/2002JC001350, 2003.

Dethleff, D., Rachold, V., Tintelnot, M., and Antonow, M.: Sea-ice transport of riverine particles from the Laptev Sea to Fram Strait based on clay mineral studies, Int. J. Earth Sci., 89, 496-502, 2000.

Gardner, W.D.: Incomplete extraction of rapidly settling particles from water samplers, Limnol. Oceanogr., 22, 764-768, 1977.

Gardner, W. D., Biscaye, P. E., Zaneveld, J. R. V., and Richardson, M. J.: Calibration and comparison of the LDGO nephelometer and the OSU transmissometer on the Nova Scotian Rise, Mar. Geol., 66, 323-344, 1985.

Gardner, W. D., Richardson, M. J., Carlson, C. A., Hansell, D., and Mishonov, A. V.: Determining true particulate organic carbon: bottles, pumps and methodologies, Deep-Sea Res. Pt. II, 50, 655-674, 2003.

Gordon, D. C. and Cranford, P. J.: Detailed distribution of dissolved and particulate organic matter in the Arctic Ocean and comparison with other ocean regions, Deep-Sea Res., 32(10), 1221$1232,1985$.

Guay, C. K. H., McLaughlin, F. A., and Yamamoto-Kawai, M.: Differentiating fluvial components of upper Canada Basin waters on the basis of measurements of dissolved barium combined with other physical and chemical tracers, J. Geophys. Res., 114, C00A09, doi:10.1029/2008JC005099, 2009.

Hunkins, K., Thorndike, E. M., and Mathieu, G.: Nepheloid Layers and Bottom Currents in the Arctic Ocean, J. Geophys. Res., 74, 28, 6995-7008, 1969.

Jackson, J. M., Carmack, E. C., McLaughlin, F. A., Allen, S. E., and Ingram, R. G.: Identification, characterization and change of the near-surface temperature maximum in the Canada Basin, 1993-2008, J. Geophys. Res., 115, C05021, doi:10.1029/2009JC005265, 2010.

Jones, E. P. and Anderson, L. G.: On the origin of the chemical properties of the Arctic Ocean halocline, J. Geophys. Res., 91, C9, 10759-10767, 1986.

Kinney, P. J., Loder, T. C., and Groves, J.: Particulate and dissolved organic matter in the Amerasian Basin of the Arctic Ocean, Limnol. Oceanogr., 16, 132-137, 1971.

Kitchen, J. C., Zaneveld, J. R. V., and Pak, H.: Effect of particle size distribution and chlorophyll content on beam attenuation spectra, Appl. Opt., 21, 3913-3918, 1982.

Lalande, C., Forest, A., Barber, D. G., Gratton, Y., and Fortier, L.: Variability in the annual cycle of vertical particulate organic carbon export on the Arctic shelves: Contrasting the Laptev Sea, Northern Baffin Bay and the Beaufort Sea, Cont. Shelf Res., 29, 2157-2165, 2009.

Lee, S. H., and Whitledge, T. E.: Primary and new production in the deep Canada Basin during summer 2002, Polar Biology, 28, 190-197, 2005.
Macdonald, R. W., Solomon, S. M., Cranston, R. E., Welch, H. E., Yunker, M. B., and Gobeil, C.: A sediment and organic carbon budget for the Canadian Beaufort Shelf, Mar. Geol., 144, 255273, 1998 .

Matrin, J., Tremblay, J.-E., Gagnon, J., Tremblay, G., Lapoussire, A., Jose, C., Poulin, M., Gosselin, M., Gratton, Y., and Michel, C.: Prevalence, structure and properties of subsurface chlorophyll maxima in Canadian Arctic waters, Mar. Ecol. Prog.-Ser., 412, 69-84, doi:10.3354/meps08666, 2010.

Mathis, J. T., Pickart, R. S., Hansell, D. A., Kadko, D., and Bates, N. R.: Eddy transport of organic carbon and nutrients from the Chukchi Shelf: Impact on the upper halocline of the western Arctic Ocean, J. Geophys. Res., 112, C05011, doi:10.1029/2006JC003899, 2007.

McLaughlin, F. A., Carmack, E. C., Zimmerman, S., Sieberg, D., White, L., Barwell-Clarke, J., Steel, M., and Li, W. K. W.: Physical and Chemical data from the Canada Basin, August, 2004, Can. Data Rep. Hydrog. Ocean Sci., 140, 1-185, 2008, http://www.ocean-sci.net/140/1/2008/.

Melling, H. and Lewis, E. L.: Shelf drainage flows in the Beaufort Sea and their effect on the Arctic Ocean pycnocline, Deep-Sea Res. 29, 967-985, 1982.

Nishino, S., Itoh, M., Yamamoto-Kawai, M., and Chiba, S.: East-west differences in water mass, nutrient, and chlorophyll $a$ distributions in the sea ice reduction region of the western Arctic Ocean, J. Geophys. Res., 113, C00A01, doi:10.1029/2007JC004666, 2008.

O’Brien, M.C., Macdonald, R.W., Melling, H. and Iseki, K.: Particle fluxes and geochemistry on the Canadian Beaufort Shelf: Implications for sediment transport and deposition, Cont. Shelf Res., 26, 41-81, 2006.

Pegau, W. S.: Inherent optical properties of the central Arctic surface waters, J. Geophys. Res., 107, C10, doi:10.1029/2000JC000382, 2002.

Pfirman, S., Gascard, J. C., Wollenburg, I., Mudie, P., and Abelmann, A.: Particle-laden Eurasian Arctic sea ice: observations from July and August 1987, Polar Res., 7, 59-66, 1989.

Pickart, R. S.: Shelfbreak circulation in the Alaskan Beaufort Sea: Mean structure and variability, J. Geophys. Res., 109, C04024, doi:10.1029/2003JC001912, 2004.

Proshutinsky, A., Krishfield, R., Timmermans, M.-L. Toole, J., Carmack, E., McLaughlin, F., Williams, W. J., Zimmerman, S., Itoh, M., and Shimada, K.: Beaufort Gyre freshwater reservoir: State and variability from observations, J. Geophys. Res., 114, C00A10, doi:10.1029/2008JC005104, 2009.

Wheeler, P. A., Gosselin, M., Sherr, E., Thibault, D., Kirchman, D. L., Benner, R., and Whitledge, T. E.: Active cycling of organic carbon in the central Arctic Ocean, Nature, 380, 697-699, 1996.

Wheeler, P. A., Watkins, J. M., and Hansing, R. L.: Nutrients, organic carbon and organic nitrogen in the upper water column of the Arctic Ocean: implications for the sources of dissolved organic carbon, Deep-Sea Res. Pt. II, 44(8), 1571-1592, 1997.

Yamamoto-Kawai, M., McLaughlin, F. A, Carmack, E. C., Nishino, S., Shimada, K., and Kurita, N.: Surface freshening of the Canada Basin, 2003-2007: River runoff versus sea ice meltwater, J. Geophys. Res., 114, C00A05, doi:10.1029/2008JC005000, 2009. 